\title{
The Role of Self Confidence Towards Gender- Based Career Planning
}

\author{
Nova Lina Eldasari* \\ Department of Postgraduate Guidance and Counseling Program \\ Universitas Negeri Yogyakarta \\ Yogyakarta, Indonesia \\ Novalina.2018@student.uy.ac.id*
}

Rosita Endang Kusmaryani

Department of Psychology

Universitas Negeri Yogyakarta

Yogyakarta, Indonesia

Rosita_ek@student.uny.ac.id

\author{
Eka Agustina \\ Department of English Education \\ STKIP Nurul Huda \\ Palembang, Sumatera Selatan \\ ekaagustina@stkipnurulhuda.ac.id
}

Andika Ari Saputra

Department of NU Islamic Institute of Religion Ma'arif

Lampung, Indonesia

\begin{abstract}
Self-confidence has an important role for everyone, both men and women. The problem of low self-confidence can create obstacles in the areas of learning, personal-social, and career life. The objective of this research was to determine career planning on the level of student confidence based on gender. The method used is a survey method. To collect the data the researcher used a scale of confidence. The total sample in this research was 92 students with a sampling technique using total sampling. For the Data analysis the writer used quantitative and qualitative analysis. The result of this research showed the level of student confidence based on gender in the category of high, as many as 35 of 43 male respondents with a percentage of $82 \%$ and as many as 36 of 49 female respondents with a percentage of $73 \%$, which included aspects of, a) self-confidence, b) responsible, and c) ability to overcome problems. The majority of respondents plan to be confident in a career planning, it is known that a high level of confidence in the increasing of career planning.
\end{abstract}

Keywords-career planning, self-confidence, gender

\section{INTRODUCTION}

The selection of individual careers is used as a bridge to make it easier to hone and develop their potential. In determining career readiness and career choices, someone should plan their careers carefully, career planning activities are very important for individuals, especially to build students' attitudes in taking future careers [1,2].

Career planning involves identifying career-related goals and compiling plans to achieve these goals with an orientation towards the development and needs of a person [3]. Through career planning, each individual evaluates his own abilities and interests, considers alternative career opportunities, sets career goals, and plans practical development activities.

Individual confidence is related to career planning. As you know, self-confidence has an important role in human life from various aspects. Generally, confidence is defined as an internal feeling of an individual's acknowledgment of his abilities, loving himself, being aware of his own emotions, and being responsible for his actions and a belief that individuals can complete tasks and goals throughout life and goals in reaching the future $[4,5,6]$. Individuals who have confidence generally like themselves, are willing to take risks, can be responsible and able to solve problems to achieve their personal and professional goals and think positively about the future.

On the other hand, self-confidence depends on how a person feels accepted and loved by others and how valuable that person is to himself. Studies have shown that selfconfidence is directly related to several factors such as selfesteem, unconditional self-acceptance, ability to take risks, do not need the approval of other $[7,8,9]$.

Lack of confidence can be caused by fear, anxiety, worry, insecurity accompanied by chest palpitations and trembling body that is psychiatric or mental problems of children caused by stimuli from outside. Besides, lack of confidence can also be caused by feelings of anxiety and uneasiness as well as other feelings that follow as lazy, impatient, difficult, difficult or low self-esteem. Students who have high self-confidence can understand their strengths and weaknesses [10,11].

Gender disparity as in the field remains large when viewed from the accumulation and discrimination of human resources even though some people or organizations are continuously striving for equality in the fields of work, academia or other fields. That is, the gap in gender roles can have an impact on psychological factors, especially the role of trust. Since young women appear less confident than men, this is used as a basis for comparison and debate when viewed from academic success, job choices, and career development [12]. For example, using college graduate data to show that women are less likely to apply for jobs with competitive compensation schemes.

The results of the study, first when asked about their level of agreement on survey questions about the economy, women were $7.6 \%$ less likely to give "extreme" answers where they strongly agreed or disagreed. Second, women 
lack confidence in the accuracy of their answers. Women expressed a confidence level of 0.340 points lower than comparable men, measured on a scale of 1 (not confident) to 10 (very confident) [13]. Overall, it can be given the meaning of a gap of a belief that persists even among the most successful academics and distinguishes between two types of beliefs where men and women differ. In other studies there is one assumption that different experiences of students, approaches to learning and confidence are all important for how they interact and what they learn in daily habits [14]. This shows that gender roles do not significantly affect a person's work.

The education world also has a role in increasing student confidence. Self-confidence can be felt by everyone especially by students to generate a sense of enthusiasm, eliminate fear, be able to make smooth career and achievement, and can be able to awaken the courage to take and face risks. Confidence can produce self-value by responding to situations faced by individuals, using students being able to interpret optimism by showing students can do things and interpreting pessimism by showing students through defensive attitudes [15].

In Hardi Prasetyawan's research [16] it is known that the level of self-confidence of SMK students The results showed that from the preliminary study showed that $6.72 \%$ of students had very high confidence categories, $23.04 \%$ of students had high confidence categories, $33,6 \%$ of students have medium category confidence, $21.12 \%$ students have low category confidence, and $7.68 \%$ of students have very low category confidence.

The education system will focus on student development, schools have an important role in facilitating students to independently students have confidence in themselves in making the right career decisions because education can affect students to explore the lives of students themselves, of course, related to careers so that students can be helped in career exploration, motivation to find work, and reflection on the career goals of the students themselves.

From the description above, it describes the level of confidence in students and the relationship between gender and career. However, it is not known in terms of gender, whether men have a higher level of confidence than women or vice versa. In addition, there is no research on whether the outcome of that confidence will affect career decision making that comes from career planning. For this reason, the authors are interested in examining more deeply, whether high confidence can be a benchmark for male and female students in career planning.

\section{METHODS}

This type of research used by researchers uses survey research that aims to obtain information on the level of student confidence based on gender. In this study, the authors used a sampling technique using total sampling. Total sampling is the same as the total population. So, the sample in this study is that all the population is sampled as many as 92 students for the distribution of scales for research purposes, then the entire population is used as a sample [17]. The method used in this research is descriptive quantitative with the type of survey with data analysis techniques using percentages (\%). With the following formula [18]:

$$
\mathrm{P}=\frac{f}{N} x 100
$$

Information:

$\mathrm{f}$ : value obtained by the respondent

$\mathrm{N}$ : maximum number of respondent's value P: Percentage

The stages in survey research are as follows; a) determine survey objectives and scores; b) scale up or interview instructions c) test instruments to identify and correct items that are less relevant to achieve a good format, easily tabulated, and easy to analyze; d) if using an interview, you should first make an interview guide; e) the instrument must have characteristics that are clear, simple, and directly related to the research problem; f) use relevant and efficient computer programs; g) consider the important characteristics of the targeted respondents, especially when conducting surveys and analyzing data; h) Imagine variations in results that might arise from survey research, including effects that might not be expected [19].

\section{RESULT AND DISCUSSION}

The results of the research and research reports obtained are studies that have the same theme. Then the data obtained are analyzed one by one to find out specifically and in detail the level of student confidence based on gender.

Result

This study aims to determine the level of student confidence based on gender. The results of the data obtained will be seen in the table.

Table 1. Level of Confidence Students Male and Female

\begin{tabular}{|c|c|c|c|c|}
\hline Gender & $\begin{array}{c}\text { Total } \\
\text { Students }\end{array}$ & Frekuensi & $\begin{array}{c}\text { Percentage } \\
(\boldsymbol{\%})\end{array}$ & Category \\
\hline Men & 43 & 35 & $82 \%$ & High \\
\hline Women & 49 & 36 & $73 \%$ & High \\
\hline
\end{tabular}

From these data shows that the level of confidence of students by gender is in the high category, as many as 35 of 43 male respondents with a percentage of $82 \%$ and as many as 36 of 49 female respondents with a percentage of $73 \%$.

There are three aspects of student confidence, namely 1) self-confidence, 2) responsibility, and 3) the ability to deal with problems. The following achievement levels of confidence based on aspects of confidence in yourself can be seen in table 2 .

Table 2. The Level of Confidence in Male and Female Students based on aspects self-confidence.

\begin{tabular}{|c|c|c|c|c|}
\hline Gender & $\begin{array}{c}\text { Number } \\
\text { of } \\
\text { Students }\end{array}$ & Frequency & $\begin{array}{c}\text { Percentage } \\
(\%)\end{array}$ & $\begin{array}{c}\text { Categories } \\
\text { of }\end{array}$ \\
\hline Men & 43 & 30 & $70 \%$ & Height \\
\hline Women & 49 & 40 & $82 \%$ & High \\
\hline
\end{tabular}

confidence of students by gender in the aspect of self- 
confidence is in the high category, as many as 30 of 43 male respondents with a percentage of $70 \%$ and as many as 40 of 49 female respondents with a percentage of $82 \%$. Based on the aspects of the responsibility level of student confidence can be seen in table 3 .

Table 3. The Level of Confidence in Male and Female Students based on aspects of responsibility.

\begin{tabular}{|c|c|c|c|c|}
\hline Gender & $\begin{array}{c}\text { Number of } \\
\text { Students }\end{array}$ & Frequency & $\begin{array}{c}\text { Percentage } \\
(\mathbf{\%})\end{array}$ & Category \\
\hline Men & 43 & 36 & $84 \%$ & Height \\
\hline Women & 49 & 30 & $80 \%$ & High \\
\hline
\end{tabular}

From the data in table 2. shows that the level of confidence of students by gender in the aspect of responsibility is in the high category, as many as 36 of 43 male respondents with a percentage of $84 \%$ and as many as 30 of 49 female respondents with a percentage of $80 \%$. The level of student confidence in the ability to deal with problems can be seen in table 4 .

Table 4. Confidence Level of Male and Female Students Based on Aspects of the Ability to Deal With Problems.

\begin{tabular}{|c|c|c|c|c|}
\hline Gender & $\begin{array}{c}\text { Number } \\
\text { of } \\
\text { Students }\end{array}$ & Frequency & $\mathbf{( \% )}$ & Category \\
\hline Men & 43 & 40 & $93 \%$ & High \\
\hline Women & 49 & 39 & $80 \%$ & High \\
\hline
\end{tabular}

From the data in table 2 . shows that the level of student confidence based on gender in the ability to deal with problems is in the high category, as many as 40 of 43 male respondents with a percentage of $84 \%$ and as many as 39 of 49 female respondents with a percentage of $80 \%$

\section{Discussion}

Based on data and analysis results regarding the level of student confidence according to gender, it can be explained as follows: 1) the level of student confidence by men and women is in the high category according to each number of respondents; 2) the level of student confidence between men and women by category is high. That is, students are confident in their abilities that they are serious about what will be done; 3) the level of student confidence between men and women based on the aspect of responsibility is in the high category. That is, students have the willingness to bear everything that has become a consequence, and 4) the level of student confidence between men and women based on the ability category in dealing with problems is in the high category. That is, students can solve problems against an event using a thought that is acceptable according to reality.

The confidence of male and female students is in the high category, meaning that between male and female students have confidence in themselves and have. A good outlook in dealing with all things about themselves hopes and have a positive attitude to their abilities. In line with the meaning of self-confidence, which is the positive attitude a person has by showing the potential for him to develop a positive assessment of himself and his environment. The element of confidence in the abilities achieved is based on students 'confidence in students' abilities and knowledge in maximizing them $[20,21]$.

A positive attitude towards yourself will affect the objective assessment, meaning that students who have high confidence will have the ability to take responsibility and look at all problems or everything according to the truth they should, not truths according to themselves or others whose truth is unknown. Self-confidence enables you to accomplish what is done without feeling haunted by guilt $[22,23]$. So, when students are faced with a problem will be willing to bear everything that has become a consequence.

The ability of individuals to complete what is done will affect rational and realistic attitudes. That is, students who have high confidence will be able to analyze a problem, a thing, and one by using thoughts that can be accepted by reason and by reality. In line with this, self-confidence is a mental ability and internal control to reduce negative feelings of doubt about the ability and responsibility for decisions that have been determined by using rational and realistic thinking [24, 25].

Negative feelings of doubt about the ability and responsibility for decisions that have been determined to affect the level of confidence in the career planning process. Influence of self-confidence contained in the person concerned in which there is self-efficacy or confidence in the individual, if individuals have a high level of confidence in themselves, career planning will increase [26, 27]. Career planning is a set of knowledge of attitudes and skills possessed by individuals in developing ways or strategies regarding the preparation of further education or work choices to realize their goals and future goals [28, 29]. Career planning involves identifying career-related goals and compiling plans to achieve those goals. High student career planning is influenced by students' career goals. Career goals can increase self-awareness and understanding, achieve personal satisfaction, prepare for adequate placement in a career, streamline the time and effort done in a career, match individuals with work, both in terms of job choice and training accordingly, as well as helping plan career activities [30, 31]. The existence of planning will help the individual in seeing what work is ideal for him.

When students have determined career goals students will find several elements that can support career planning. Some aspects of related individuals are selfunderstanding, knowledge, and understanding of the world of work, and realistic reasoning about the relationship of knowledge and self-understanding and understanding of secondary school or the world of work. These aspects can be a reference to see the level of student career planning [32, 33]. Confidence will affect the ability of individuals in completing what is done, have a high level of confidence in themselves with the category of career planning will increase. The majority of students between men and women want to be able to plan their careers, it is known that a high level of trust in increasing the amount of career planning. The author is interested in conducting deeper research related to the level of confidence between male and female students in career planning. 


\section{ACKNOWLEDGMENT}

Thank you to the characters at the writing of this article for providing references so that they add information and insight to the author.

\section{REFERENCES}

[1] Supriatna, dkk. (2010). Layanan Bimbingan Karir di Sekolah Menengah Kejurua. Bandung: Departemen Pendidikan Nasional UPI.

[2] Pritangguh, M. (2017). Peningkatan Kemampuan Perencanaan Karier Melalui Bimbingan Kelompok Teknik Diskusi pada Siswa SMPN 3 Kebumen. E-Journal Bimbingan dan Konseling Edisi 2 , Vol. 6.

[3] Witko, D. K., Bernes, B. K., Magnusson, C. K., \& Bardick, D. A. (2013). Senior High Students' Career Plans For the Future: Outcomes of the Comprehensive Career Needs Survey. Int J Educ Vocat Guid, 6:77-94.

[4] Iovu, B. M. (2013). Senior High School Students' Job Planning For: The Future: What Factors Really Matter? Revista de Asistenta Sociala , Vol 1. 59-70.

[5] Sar, H. A., Avcu, R., \& Isiklar, A. (2010). Analyzing Undergraduate Students' Self Confidence Levels in Terms of Some Variables. Procedia Social and Behavioral Sciences, Vol. 5. 1205-1209

[6] Pratiwi, D. I. (2016). Kepercayaan Diri dan Kemandirian Belajar Pada Siswa SMA Negeri "X". Jurnal Psikologi Teori \&Terapan, Vol.7, No.1 .

[7] Vanaja, Y., \& Geetha, D. (2017). A Study On Locus of Control and Self Confidence Of. Internasional Journal of ResearchGranthaalayah, Vol.5.

[8] Jahanbakhsh, S., Jomehri, F., \& Mujembari, A. K. (2015). The Comparison of Women's Self Confidence in Base of Gender Role. Procedia - Social and Behavioral Sciences, 2285 - 2290

[9] Gosling, S. D. (2016). Age and Gender Differences in Self-EsteemA Cross-Cultural Window. Journal of Personality and Social Psychology, , Vol. 111, No. 3, 396-41

[10] Usta, G. H. (2017). Examination of the Relationship Between TEOG Score Transition from Basic to Secondary Education), SelfConfidence,Basic to Secondary Education), Self-Confidence,. Journal of Education and Practice, Vol.8, No.6.

[11] Aristiani, R. (2016). Meningkatkan Percaya Diri Siswa Melalui Layanan Informasi Berbantuan Audiovisual. Jurnal Konseling Gusjigang, Vol. 2 No. 2

[12] Greenacre, L. (2014). Self confidence, and the ability to influence. Academy of Marketing Studies Journal, 18(2), 169-180.

[13] Sarsons, H., \& Xu, G. (2015). Confidence Men? Gender and Confidence:Evidence among Top Economists. Littauer Center,

[14] Jakabsson, A. (2006). Students' Self-Confidence and Learning Through Dialogues in a Net-Based Environment. Jl. of Technology and Teacher Education, 387-405.

[15] Sharma, S., \& Sahu, D. (2013). Effect of Social Networking Sites on Self Confidence. International Journal of Information and Computation Technology, Volume 3, pp. 1211-1216.
[16] Prasetiawan, H. (2018). Pemanfaatan Media Bimbingan dan Konseling di Sekolah Menengah Kejuruan Muhammadiyah se-Kota Yogyakarta. Jurnal Kajian Bimbingan dan Konseling , 3(1), pp. 1421.

[17] Arikunto, S. 2010. Prosedur Penelitian Suatu Pendekatan Praktik. Jakarta: PT Rineka Cipta.

[18] Setiawati, F. A. (2017). Statistika Terapan. Yogyakarta: Parama Publishing.

[19] Sugiyono. (2016). Metode Penelitian Pendidikan. Bandung: Alfabeta.

[20] Fatimah, 2006. Panduan Remaja Meraih Sukses. Jakarta : Pustaka Populer Obor.

[21] Ifdil, I., Denich, U. A., \& Asmidir, I. (2017). Hubungan Body Image dengan Kepercayaan Diri. Jurnal Kajian Bimbingan dan Konseling , 107-113.

[22] Dewi, D. M., Supriyo, \& Suharso. (2013). Kepercayaan Diri Ditinjau dari Pola Asuh Orang Tua pada Siswa Kelas VII . Indonesian Journal of Guidance and Counseling: Theory and Aplication, Vol.2.

[23] Singh, T., \& P., K. (2008). Effect of Meditation on Self Confidence of Student- Teachers in Relation to Gender and Religion. Journal of Exercise Science and Physiotherapy, Vol. 4, No. 1: 35-43.

[24] Anita Lie. 2003. Cooperatif Learning: Mempraktekkan Cooperatif Learning di Ruang-Ruang Kelas. Jakarta: Gramedia.

[25] Sharma, M. (2016). A Study of Self-Confidence of Senior Seconadry Schol Student in Relation to Socio-Economic Status. American International Journal of Research in Humanities, Arts and Social Sciences, pp. 78-80.

[26] Novakovic, Alexandra dan Nadya A. Fouad. 2012. Background, Personal, and Environmental Influences on the Career Planning of Adolescent Girls. Journal of Career Development. 40 (3): 223-244.

[27] Hasibuan, N. A., \& Syahrizal. (2019). Pengaruh Efikasi Diri Terhadap Perencanaan Karir Karyawan denganMotivasi Karir Sebagai Variabel Mediasi pada PT. Padang IntermediaPers Bagian Padang Ekspres Kota Padang, Sumatera Barat. Jurnal Kajian Manajemen dan Wirausaha, Volume 01 Nomor 02.

[28] Supriatna, dkk. (2010). Layanan Bimbingan Karir di Sekolah Menengah Kejurua. Bandung: Departemen Pendidikan Nasional UPI.

[29] Pascual, N. T. (2014). Factors Affecting High School Students' CareerPreference: A Basis for Career Planning Program. International Journal of Sciences: Basic and Applied Research (IJSBAR), Volume 16, No 1, pp 1-14.

[30] Kim Witko, dkk. 2005. "Senior High School Career Planning: What Students Want". Journal of Educational Enquiry, Vol. 6, No. 1, pp.: 34-49.

[31] Su, M.-S. S., Chang, T.-C., Wu, C. C., \& Liao, C.-W. (2016). Factors Affecting the Student Career Decision-Making of Junior High School Students in Central Taiwan Area. International Journal of Information and Education Technology, Vol. 6, No. 11.

[32] Winkel, W. S. (2013). Bimbingan dan Konseling di Institusi Pendidikan. Jakarta: Gramedia.

[33] Pradana, T. A., Sutoyo, A., \& Japar, M. (2018). The Effectiveness of Career Information Service with Mind Mapping Technique to Improve Students Occupational Knowledge. Jurnal Bimbingan Konseling, Vol. 7 pp $23-27$ 